\title{
Performance and Stability of Different Zone Specific Genotypes Evaluated against Spot Blotch of Wheat
}

\author{
Sunita Mahapatra ${ }^{1}$, Hizam Meronbala Devi ${ }^{1}$, Satish Kumar $^{3}$, \\ Dhiman Mukherjee ${ }^{2}$ and Srikanta Das ${ }^{1}$
}

${ }^{1}$ Department of Plant Pathology, ${ }^{2}$ In-Charge, AICRP Wheat, Agronomist, Bidhan Chandra Krishi Viswavidyalaya, Kalyani, Nadia.741252, India

${ }^{3}$ Crop Improvement Division, ICAR-Indian Institute of Wheat and Barley Research, Karnal- 132001, India

*Corresponding author

\section{A B S T R A C T}

\section{Keywords \\ Spot blotch, Stability, Disease severity, Disease resistance, Wheat genotypes}

\section{Article Info}

Accepted:

18 May 2020

Available Online:

10 June 2020
A total of 117 wheat genotypes from different zones of India i.e. 35 from NEPZ, 34 from CZ, 29 from NWPZ and 19 from PZ were screened for resistance against spot blotch of wheat for three consecutive years (2015-16, 2016-17 and 2017-18) at disease hot spot location, Kalyani, to find out the most suitable varieties for cultivation for this zone. These genotypes were also tested for their stability on disease reactions obtained during three years of testing. The overall analysis of pooled data showed that the genotypes and environment significantly affected the reactions to spot blotch and variation in disease severity was noticed among genotypes and across the environments. The genotype environment interaction was also highly significant for disease severity. This indicated that the spot blotch disease severity in the genotypes has divergent linear responses to environmental changes. Deviation from linear regression has contributed substantially towards differences in stability of disease reactions on genotypes. It was found that both predictable (linear) and unpredictable (non-linear) components contributed to the differences in stability of disease reaction (resistance, moderately resistant/ tolerant) among genotypes. Based on the disease tolerance reaction, out of the 117 tested genotypes, K8027, C306 and Raj4240 from NEPZ; HI8730(d), HI8726(d), MP1259, GW1280(d) and HI1500 from CZ; PBW665 from NWPZ and HI8728(d), HI8725(d), MACS6222, NIDW295(d) and AKAW4731 from PZ could be used to develop improved genotypes with spot blotch resistance which are suitable for Indo-Gangetic plains of India.

\section{Introduction}

During 2018-19 wheat production in India made a history by producing 101.20 million tones from approximately 30 million hectares of land, registering an all-time highest crop productivity of $3424 \mathrm{~kg} / \mathrm{ha}$ (Annual Progress Report, 2018-19). But the percentage decline in acreage was highest in case of North
Eastern Plain Zone (NEPZ) that is due to disease pressure and restriction of wheat cultivation in some areas of West Bengal due to wheat holidays (ICAR-IIWBR, 2018). In North Eastern plain zone of India is always in back foot due to higher intensity of spot blotch which causes yield losses (18-50\%) it depends on cultivar and weather factors (Singh et al., 2015) and with one percent 
increase in spot blotch disease severity causes makeable loss in yield and yield attributes (Devi et al., 2018). In West Bengal as well as all over Eastern India the main important fungal disease is foliar blight caused by Bipolaris sorokiniana and Alternaria triticina may attack singly or together and caused a loss of yield exceeding 60\% (Prabhu and Singh, 1974).

In recent years spot blotch caused by Bipolaris sorokiniana has caused serious damage on wheat crop in India, particularly in Eastern and Central India. As problem of spot blotch is more prominent in the north eastern region and is being addressed through national program as well as linkages with CIMMYT- South Asia and co-operators located in the region (Kumar et al., 2016; Chowdhury et al., 2013; Chaurasia et al., 1999). Considering high yield losses, breeding for resistance demands high priority (Joshi et al., 2007). It is necessary to have ample genetic variability within the host population intensive efforts in many countries are now underway to identify the sources of resistance to spot blotch of wheat.

As the cultivation of wheat in NEPZ in India is demanding for increasing food production and farmers are cultivated the crop without knowing the proper cultural practices which decrease the yield by increasing the important disease like spot blotch. No information has been available regarding the nature of this disease, losses caused by them, epidemiology and management in these agro climatic zones. Even every year contribution of new disease resistant variety in national breeding program is not appreciated. Several workers were screened the wheat varieties/ genotypes against spot blotch of wheat, but no one found immune though some were tolerant and moderately resistant in different parts of the country (Pandey and Tiwari, 1999, Singh et al., 2015, Kumar et al., 2020). Breeding for disease resistance is most efficient and cheaper methods for managing spot blotch of wheat. In India the resistance levels to this disease in the wheat varieties have been found lacking and hence huge losses are incurred at the farmers' fields (Joshi et al., 2007; Singh et al., 2015). Resistant donors from Africa, Brazil and China were the earliest sources of resistance used in the breeding programs. BH1146 from Brazil is still one of the most important sources of resistance to this disease. Chinese germplasm such as Yangmai 6, Ning 8201 and Chirya 3 have also been used extensively in the resistance breeding. Genotypes that accumulate three to four desirable resistance alleles are desired for an efficient control of spot blotch.

This experiment was conducted to (i) screen a large number of genotypes to identify resistant, moderately resistant and tolerant genotypes and (ii) assess the statistical probability of resistance, moderately resistant and tolerant ones for the stability of these traits to identify genotypes to be suitable for this zone and can be also used in future breeding program.

\section{Materials and Methods}

Experiments were carried out during winter season of three consecutive years (2015-16, 2016-17 and 2017-18) to screen the 117 genotypes of wheat against the spot blotch of wheat under Gangetic alluvial zones of West Bengal. The genotypes were collected from IIWBR, Karnal, India.

\section{Experimental sites}

The field experiments were carried out at Instructional Farm, Jaguli of Bidhan Chandra Krishi Viswavidyalaya (BCKV), Nadia, West Bengal, India during 2015-18 (three consecutive years). Though it is known as hot spot fpr spot blotch of wheat, but to create 
more diseases pressure made two time artificial inoculation one at seed stage and another one at boot leaf stage (Plate.2).

\section{Agro-climatic condition of the research station}

The research station is situated at an elevation of 9.75 meter above sea level and the latitude and longitude are $23.5{ }^{\circ} \mathrm{N}$ and $89.0{ }^{\circ} \mathrm{E}$, respectively. The climate of this region is subtropical humid and the entire year can be classified into three distinct seasons viz., winter season which is short and mild, starting from middle of October which extends up to middle of February, temperature is mild ranging from $10-28^{\circ} \mathrm{C}$. The normal average annual rainfall is $1396 \mathrm{~mm}$ and about $80 \mathrm{~cm}^{-1}$ is received during the month of June to October and only a scanty rainfall occurs during the growth period of wheat (November to February). The climatic condition prevailing during the period of investigation was winter seasons. It is known as hot spot zone for spot blotch of wheat.

\section{Procedure of disease assessment for spot blotch of wheat}

IARI double digit scale was used for screening the genotypes against spot blotch of wheat, the severity was assessed on percentage of leaf area covered by the spot blotch pathogens i.e. severity. Actually the present coverage or severity was scored just like in case of wheat rust scoring. 10-20 plants were looked at an overall, score at flag leaf and in the leaf just below the flag leaf were decided. As it was often difficult to score the spot blotch disease on dead leaves, disease scoring was taken on the green leaves. Observations were taken only in the middle rows. The two border rows were always avoided to avoid buffer effect (Plate.1). The proposed rating system as double digit rating scale has the digits rating 0-9 and severity was recorded on the top two leaves of the plant at 59-65 growth stages of Zadok's scale (Zadoks et al., 1974). The blight severity is taken in percent leaf area covered separately for flag (F) and leaf below flag (F-1).In no case the value of right hand side should be lower than the value of left hand side digit since the disease progresses from down to top.

\section{Screening of different varieties for disease resistance and their stability}

The observations were made at dough and hard dough stage of the wheat crop. The varieties were graded into six groups on the basis of disease reaction following (Saari and Prescot, 1975). Different varieties of wheat were rated by double digit scoring method and were classified according to their varietal responses. The classification was done under following categories

\begin{tabular}{|l|l|c|l|}
\hline \multicolumn{2}{|c|}{ Type } & \multicolumn{2}{c|}{ Description } \\
\hline I & Immune & 00 & No infection \\
\hline R & Resistant & $\leq 15$ & Percent disease infection \\
\hline MR & Moderately resistant & $\leq 37$ & Percent disease infection \\
\hline MS & Moderately susceptible & $\leq 56$ & Percent disease infection \\
\hline S & Susceptible & $\geq 57$ & Percent disease infection \\
\hline HS & Highly susceptible & $\geq 79$ & Percent disease infection \\
\hline
\end{tabular}


The PDI determined for the germplasm was subjected to analysis of variance, regression coefficients were work out and deviation from regression was calculated to assess the potential stability of the germplasm (Eberhart and Russell, 1966).

\section{Results and Discussion}

A stable genotype is desirable for its commercial exploitation over a wide range of agro-climatic conditions. Its adaptability in real sense is governed by its genetic makeup. Preliminary evaluation can be done to identify stable genotypes through screening over several years. Data on spot blotch severity obtained from a number of promising genotypes of wheat can be screened and the promising genotypes subjected to stability analysis to obtain information on genotype $\mathrm{x}$ environmental interaction. The overall analysis of pooled data (Table 1, 2, 3, 4) showed that the genotypes and environment significantly affected diseases reaction to spot blotch. Variation in disease severity was noticed among genotypes and environment. The genotypes and environment interaction was also highly significant for this character (spot blotch disease severity). This indicated that the spot blotch disease severity in the genotypes has divergent linear responses to environmental changes. It was also noticed that the pooled deviation was also significant. This deviation from linear regression has contributed substantially towards differences in stability of resistance of genotypes. It was found that both predictable (linear) and unpredictable (non-linear) components contributed to the differences in stability of disease reaction (resistance, moderately resistant/ tolerant) among genotypes.

According to these workers, phenotypic stability can be measured by three parameters, namely mean performance over environment (Xi), linear regression (bi) and deviation from regression $\left(S^{2} \mathrm{di}\right)$. The estimate of bi and $\mathrm{S}^{2} \mathrm{di}$ showed that there were distinct differences among the genotypes in respect of their deviation around the regression. The genotypes were graded into two groups on the basis of mean disease intensity and later genetic stability against resistance could be measured by low disease severity and low deviation from regression $\left(\mathrm{S}^{2} \mathrm{di}<1\right)$ and high regression value $(\mathrm{bi} \geq 1)$.

\section{Stability of disease reaction of genotypes from north eastern plain zone (NEPZ)}

No immune and highly susceptible genotypes were found in this tested genotype. Out of the 35 wheat genotypes tested only one genotypes HD 2888 was found resistant and was expected to be unstable with a regression coefficient ( $\mathrm{bi}=0.92)$ and deviation from regression $\left(\mathrm{S}^{2} \mathrm{di}=9.43\right)$. Among 35 genotypes tested, only six genotypes HD 2733, Raj 4240, WH 1127, DBW 39, K 8027 and C 306 were found moderately resistant, 16 genotypes were moderately susceptible and others were susceptible. Among the moderately resistant genotypes, WH 1127 was expected to be stable with a regression coefficient $(\mathrm{bi}=1.75)$ and deviation from regression $\left(\mathrm{S}^{2} \mathrm{di}=2.02\right)$. This variety persistently showed low disease severity $(25.93 \%, 24.69 \%, 17.28 \%$ and $22.63 \%)$ for the year 2015-2016, 2016-17, 2017-18 and pooled mean respectively. Although low disease severity was recorded in K 8027 (19.34\%), C 306 (25.51\%) and Raj 4240 (30.04\%), though the reactions were moderately resistant but due to high deviation from regression $\left(\mathrm{S}^{2} \mathrm{di}=4.98,8.75\right.$ and 8.12$)$ and low regression coefficient $(\mathrm{bi}=0.76,1.19$ and 1.47) respectively proved that this moderately resistant genotype was to some extent stable in disease reaction (Table 5).Moderately resistant genotypes DBW 39 (26.75\%) and HD 2733 (26.75\%) were also found unstable due to high deviation from 
regression and low regression coefficient. Among the 16 moderately susceptible genotypes no genotype has been found to be stable.

\section{Stability of disease reaction from central zone $(\mathbf{C Z})$}

No immune and resistant genotypes were found in these tested genotypes. Among thirty four genotypes tested, nine genotypes were found moderately resistant, four genotypes were found susceptible and others were moderately susceptible. Among the nine moderately resistant genotypes, HI 8730 was expected to be stable with a high regression coefficient $(\mathrm{bi}=0.90)$ and low deviation from regression $\left(\mathrm{S}^{2} \mathrm{di}=-0.07\right)$. This variety persistently showed low disease severity $(34.57 \%, 29.63 \%, 25.93 \%$ and $30.04 \%)$ for the year 2015-2016, 2016-17, 2017-18 and pooled mean respectively.

The other moderately resistant genotypes like GW322 (Xi= 29.63\%), MPO 1255(d) $(\mathrm{Xi}=$ $29.63 \%)$ and MPO 1256(d) $(\mathrm{Xi}=26.34 \%)$ were highly stable in their disease reaction due to low deviation from regression $\left(\mathrm{S}^{2} \mathrm{di}=\right.$ $0.36,-0.36$ and -0.02 ) and high regression coefficient (bi $=1.02,1.02$ and 1.66) respectively (Table 6). The moderately resistant genotypes HI 8726(d), MP 1259, GW 1280(d) and HI 1500 were also found to be stable in disease reaction.

Similarly taking the same criteria into consideration, out of the 21 moderately susceptible genotypes, HI 8728 and HI 8713 was highly stable among the others due to low deviation from regression $\left(\mathrm{S}^{2} \mathrm{di}=0.76\right.$ and $0.61)$ and high regression coefficient (bi= 1.02 and 1.00 ) respectively.

The others moderately susceptible genotypes were highly unstable in their disease reaction (Table 6).No susceptible varieties have been found to be stable due to high deviation from regression and high regression coefficient.

Stability of disease reaction of genotypes
from north-western plain zone (NWPZ)

Among twenty-nine genotypes tested, three genotypes were found moderately resistant, twelve genotypes moderately susceptible and others were susceptible. No immune and resistant reactions were found in these tested genotypes. Among the three moderately resistant genotypes, PBW 665 was expected to be stable with a regression coefficient (bi= $0.95)$ and deviation from regression $\left(\mathrm{S}^{2} \mathrm{di}=\right.$ 2.98). This variety persistently showed low disease severity $(22.22 \%, 24.69 \%, 18.52 \%$ and $21.81 \%$ ) for the year 2015-2016, 2016$17,2017-18$ and pooled mean respectively.

Whereas, variety HD $3080(26.75 \%)$ and DBW 88 (30.04\%) showed the low disease severity in the pooled mean but due to high deviation from regression $\left(\mathrm{S}^{2} \mathrm{di}=11.81\right.$ and 10.23) respectively and low regression coefficient (bi $=0.21$ and 1.24) respectively proved that these moderately resistant genotypes were unstable in disease reaction. Among this moderately susceptible genotype HD 3081 was highly stable among the others due to low deviation from regression $\left(\mathrm{S}^{2} \mathrm{di}=\right.$ 0.79) and high regression coefficient (bi= 1.39). Similarly, in case of susceptible genotypes only one genotype HD 3091 (63.59\%) was highly stable among the others due to low deviation from regression $\left(\mathrm{S}^{2} \mathrm{di}=\right.$ 0.52 ) and high regression coefficient (bi= 1.29) (Table 7).

\section{Stability of disease reaction of genotypes from peninsular zone (PZ)}

Among the nineteen genotypes, moderately resistant genotype was assessed belonged to HI 8728, HI 8725, MACS 6222, NIDW 295 and AKAW 4731. 
Of these, MACS 6222 proved most promising and was expected to be stable with a high regression coefficient $(\mathrm{bi}=1.08)$ and low deviation from regression $\left(\mathrm{S}^{2} \mathrm{di}=-0.33\right)$. This variety persistently showed low disease severity $(29.63 \%, 24.69 \%, 18.52 \%$ and $24.28 \%$ ) for the year 2015-2016, 2016-17, 2017-18 and pooled mean respectively.

Whereas, the low disease severity was recorded in AKAW 4731 $(\mathrm{Xi}=26.75 \%)$ and NIDW 295 ( $\mathrm{Xi}=30.04 \%)$, the high deviation from regression $\mathrm{S}^{2} \mathrm{di}=11.59$ and 28.04 respectively and low regression coefficient bi $=0.16$ and 0.42 respectively proved that this moderately resistant genotypes were unstable in disease reaction.

Though moderately resistant genotypes HI 8728 and NIDW 295 produced low disease severity and also high regression value $(\mathrm{bi}=$ 0.83), low deviation from regression $\left(S^{2} \mathrm{di}=0.61\right)$ proved that these genotypes were also to some extend stable in disease reaction (Table 8).

Similarly, taking the same criteria into consideration, moderately susceptible stable genotypes included only one i.e. UAS 336 (Xi $=48.09 \%$; bi $\left.=1.55 ; \mathrm{S}^{2} \mathrm{di}=0.17\right)$. Besides these, some moderately susceptible genotype showed low regression coefficient but high deviation from regression. Only one genotype HD 2932 was found to be susceptible ( $\mathrm{Xi}=$ 71.19\%; bi = 1.04; $\mathrm{S}^{2} \mathrm{di}=9.38$ ).

Every year so many varieties are released and recommended for a particular zone depends on the diseases of importance and weather conditions. But this experiment for the first time conducted to evaluate the high productive varieties from other zones to evaluate the diseases reactions against spot blotch in its hot spot area.

From the three years field experiment, a list of varieties can be recommended in the farmers's field of gangetic alluvial zone. Every zone has some restrictions that they could not be able to produce new varieties due to different weather conditions. But in that case if we follow this simple experiment by screening and stability experiment we can propose suitable varieties in spite of all limitations.

Even continuous growing of same varieties in a large area year after year may change their weather adaptability and disease reactions, so time to time deployment of different varieties are necessary to get a high yield to support the local government and farmers. Not only for recommendation for farmer's field but also the genetic back ground can be used in future breeding program.

In eastern part of India, wheat cultivation facing lots of problems like presence of warm and humid climate (Sharma et al., 2005; Joshi et al., 2004), pre harvesting spouting (Derera et al., 1977), rainfall at crop maturity, short winter etc. weather variability not only causes high disease risk of spot blotch but also cause a risk of new emerging diseases like wheat blast.

So, to un interrupted recommendation for new disease resistance varieties for cultivation, this is the only way of method for selection and cost effective. This kind of study also showed a success in case of Barley against Helminthosporium leaf blight (Mudi et al., 2010).

In case of wheat different workers (Singh et al., 2013, Khan and Chowdhury, 2011; Kumar et al., 2007) they screened a number of Indian as well as exotic germplasm but this study itself is an unique example where we using Indian genotypes with high yield and tested for their stability by genotype $\mathrm{x}$ environment interaction. 
Table.1 Pooled ANOVA for mean data (NEPZ at hard dough stage)

\begin{tabular}{|c|c|c|c|c|}
\hline Source of variation & df & SS & MS & F value \\
\hline Environment (E) & 2 & 472.98 & 236.49 & $193.59^{*}$ \\
\hline Genotype (G) & 34 & 28439.49 & 836.46 & $684.72^{*}$ \\
\hline G X E & 68 & 389.55 & 5.73 & $12.45^{*}$ \\
\hline E (linear) & 1 & 472.92 & 472.92 & $51.06^{*}$ \\
\hline G X E (linear) & 34 & 65.45 & 1.93 & 0.21 \\
\hline Pooled deviation & 35 & 324.16 & 9.26 & $20.13^{*}$ \\
\hline Pooled error & 210 & 96.62 & 0.46 & \\
\hline
\end{tabular}

Table.2 Pooled ANOVA for mean data (Central zone at hard dough stage)

\begin{tabular}{|c|c|c|c|c|}
\hline $\begin{array}{c}\text { Source of } \\
\text { variation }\end{array}$ & df & SS & MS & F value \\
\hline Environment (E) & 2 & 584.43 & 792.22 & $861.81^{*}$ \\
\hline Genotype (G) & 33 & 13415.09 & 406.52 & $442.23^{*}$ \\
\hline G x E & 66 & 442.79 & 6.71 & $18.19^{*}$ \\
\hline E (linear) & 1 & 1584.36 & 1584.36 & $203.92^{*}$ \\
\hline G X E (linear) & 33 & 178.69 & 5.42 & 0.69 \\
\hline Pooled deviation & 34 & 264.17 & 7.77 & $21.07^{*}$ \\
\hline Pooled error & 204 & 75.22 & 0.37 & \\
\hline
\end{tabular}

Table.3 Pooled ANOVA for mean data (NWPZ at hard dough stage)

\begin{tabular}{|c|c|c|c|c|}
\hline Source of variation & df & SS & MS & F value \\
\hline Environment (E) & 2 & 502.96 & 251.48 & $150.29^{*}$ \\
\hline Genotype (G) & 28 & 18017.28 & 643.47 & $384.56^{*}$ \\
\hline G x E & 56 & 298.84 & 5.34 & $8.42^{*}$ \\
\hline E (linear) & 1 & 502.88 & 502.88 & $78.60^{*}$ \\
\hline G X E (linear) & 28 & 113.37 & 4.05 & 0.63 \\
\hline Pooled deviation & 29 & 185.55 & 6.40 & $10.09^{*}$ \\
\hline Pooled error & 174 & 110.23 & 0.63 & \\
\hline
\end{tabular}

Table.4 Pooled ANOVA for mean data (Penninsular Zone at hard dough stage)

\begin{tabular}{|c|c|c|c|c|}
\hline Source of variation & df & SS & MS & F value \\
\hline Environment (E) & 2 & 1017.19 & 508.59 & $662.78^{*}$ \\
\hline Genotype (G) & 18 & 6455.80 & 358.66 & $467.38^{*}$ \\
\hline G X E & 36 & 300.42 & 8.35 & $24.91^{*}$ \\
\hline E (linear) & 1 & 1017.18 & 1017.18 & $155.82^{*}$ \\
\hline G X E (linear) & 18 & 176.40 & 9.80 & 1.50 \\
\hline Pooled deviation & 19 & 124.03 & 6.53 & $19.48^{*}$ \\
\hline Pooled error & 114 & 38.20 & 0.34 & \\
\hline
\end{tabular}


Table.5 Mean Disease severity (PDI) and parameters of stability (bi and $\mathrm{S}^{2}$ di) on wheat varieties of North Eastern Plain zone at hard dough stage grown in three environments (2015-2018)

\begin{tabular}{|c|c|c|c|c|c|c|c|c|}
\hline \multirow{2}{*}{$\begin{array}{l}\text { SL } \\
\text { No. }\end{array}$} & \multirow[t]{2}{*}{ Varieties } & \multicolumn{3}{|c|}{ Percent disease incidence (PDI) } & \multirow[t]{2}{*}{ Mean } & \multirow{2}{*}{$\begin{array}{l}\text { Regression } \\
\text { coefficient } \\
\text { (bi) }\end{array}$} & \multirow{2}{*}{$\begin{array}{c}\text { Mean } \\
\text { deviation } \\
\left(\mathbf{S}^{2} \mathbf{d i}\right)\end{array}$} & \multirow{2}{*}{$\begin{array}{l}\text { Disease } \\
\text { reaction }\end{array}$} \\
\hline & & 2015-16 & 2016-17 & 2017-18 & & & & \\
\hline 1 & HD 3076 & 47.38 & 45.51 & 43.21 & 45.37 & 0.68 & 2.11 & MS \\
\hline 2 & NW 5054 & 51.85 & 49.38 & 43.57 & 48.27 & 1.50 & 5.12 & MS \\
\hline 3 & Raj 4245 & 45.85 & 49.38 & 43.21 & 46.15 & 1.05 & 3.94 & MS \\
\hline 4 & K 0307 & 45.85 & 49.38 & 43.21 & 46.15 & 1.05 & 3.92 & MS \\
\hline 5 & HUW 652 & 45.85 & 43.21 & 39.51 & 42.86 & 1.06 & 4.82 & MS \\
\hline 6 & Raj 4229 & 49.38 & 45.85 & 43.21 & 46.15 & 0.90 & 7.79 & MS \\
\hline 7 & HD 3079 & 43.21 & 47.38 & 41.57 & 44.05 & 0.91 & 6.34 & MS \\
\hline 8 & K 1006 & 45.85 & 43.21 & 41.57 & 43.54 & 0.60 & 4.03 & MS \\
\hline 9 & NW 5038 & 49.38 & 45.85 & 43.21 & 46.15 & 0.90 & 7.77 & MS \\
\hline 10 & Raj 4246 & 51.85 & 47.38 & 45.85 & 48.36 & 0.74 & 11.60 & MS \\
\hline 11 & HD 2733 & 25.93 & 29.63 & 24.69 & 26.75 & 0.76 & 4.99 & MR \\
\hline 12 & Raj 4240 & 29.63 & 34.57 & 25.93 & 30.04 & 1.47 & 8.12 & MR \\
\hline 13 & HD 3078 & 43.21 & 39.51 & 39.51 & 40.74 & 0.33 & 7.18 & MS \\
\hline 14 & PBW 661 & 45.85 & 43.21 & 41.57 & 43.54 & 0.60 & 4.01 & MS \\
\hline 15 & UP 2822 & 66.67 & 69.14 & 61.26 & 65.69 & 1.52 & 0.87 & $\mathrm{~S}$ \\
\hline 16 & K 0906 & 59.26 & 66.67 & 61.26 & 62.40 & 0.53 & 25.09 & $S$ \\
\hline 17 & MP 3353 & 69.14 & 66.67 & 59.26 & 65.02 & 1.86 & 5.77 & S \\
\hline 18 & DBW 90 & 69.14 & 71.26 & 66.67 & 69.02 & 0.83 & 0.94 & $S$ \\
\hline 19 & RW 3705 & 77.78 & 69.14 & 66.67 & 71.19 & 1.32 & 44.04 & S \\
\hline 20 & GW 431 & 69.14 & 66.67 & 61.26 & 65.69 & 1.42 & 4.94 & $\mathrm{~S}$ \\
\hline 21 & NW 2036 & 69.14 & 69.14 & 66.67 & 68.31 & 0.55 & -0.41 & $\mathrm{~S}$ \\
\hline 22 & CG 1006 & 51.85 & 49.38 & 43.21 & 48.15 & 1.58 & 5.23 & MS \\
\hline 23 & Raj 4250 & 39.51 & 43.21 & 38.57 & 40.43 & 0.69 & 5.10 & MS \\
\hline 24 & K 0911 & 63.21 & 61.21 & 59.26 & 61.23 & 0.61 & 2.31 & $\mathrm{~S}$ \\
\hline 25 & WH 1123 & 69.14 & 66.67 & 61.26 & 65.69 & 1.42 & 4.92 & S \\
\hline 26 & DBW 14 & 69.14 & 66.67 & 63.21 & 66.34 & 0.99 & 4.16 & $S$ \\
\hline 27 & HI 1563 & 66.67 & 77.78 & 69.14 & 71.19 & 0.91 & 56.37 & S \\
\hline 28 & GW 433 & 69.14 & 77.78 & 69.14 & 72.02 & 1.13 & 32.01 & $\mathrm{~S}$ \\
\hline 29 & K 1016 & 45.85 & 43.21 & 39.51 & 42.86 & 1.06 & 4.82 & MS \\
\hline 30 & HD 2888 & 7.41 & 12.35 & 6.17 & 8.64 & 0.92 & 9.43 & $\mathbf{R}$ \\
\hline 31 & HD 3070 & 41.85 & 43.21 & 39.51 & 41.52 & 0.70 & 0.01 & MS \\
\hline 32 & WH 1127 & 25.93 & 24.69 & 17.28 & 22.63 & 1.75 & 2.02 & MR \\
\hline 33 & DBW 93 & 25.93 & 29.63 & 24.69 & 26.75 & 0.76 & 4.98 & MR \\
\hline 34 & K 8027 & 18.52 & 22.22 & 17.28 & 19.34 & 0.76 & 4.98 & MR \\
\hline \multirow[t]{2}{*}{35} & C 306 & 24.69 & 29.63 & 22.22 & 25.51 & 1.19 & 8.75 & MR \\
\hline & & Variety(V) & \multicolumn{2}{|c|}{ Environment (E) } & $\mathbf{V} \times \mathbf{E}$ & & & \\
\hline \multicolumn{2}{|c|}{ SEm ( $( \pm)$} & 0.392 & \multicolumn{2}{|c|}{0.273} & 0.678 & & & \\
\hline \multicolumn{2}{|c|}{$\mathrm{CD}(\mathrm{P}=\mathbf{0 . 0 5})$} & 1.092 & \multicolumn{2}{|c|}{0.760} & 1.891 & & & \\
\hline
\end{tabular}


Table.6 Mean Disease severity (PDI) and parameters of stability (bi and $\mathrm{S}^{2}$ di) on wheat varieties of Central zone at hard dough stage grown in three environments (2015-2018)

\begin{tabular}{|c|c|c|c|c|c|c|c|c|}
\hline \multirow{2}{*}{$\begin{array}{l}\text { SL } \\
\text { No. }\end{array}$} & \multirow[t]{2}{*}{ Varieties } & \multicolumn{3}{|c|}{ Percent disease incidence (PDI) } & \multirow[t]{2}{*}{ Mean } & \multirow{2}{*}{$\begin{array}{l}\text { Regression } \\
\text { coefficient } \\
\text { (bi) }\end{array}$} & \multirow{2}{*}{$\begin{array}{c}\text { Mean } \\
\text { deviation } \\
\left(\mathbf{S}^{2} \text { di) }\right.\end{array}$} & \multirow{2}{*}{$\begin{array}{l}\text { Disease } \\
\text { reaction }\end{array}$} \\
\hline & & 2015-16 & 2016-17 & 2017-18 & & & & \\
\hline 1 & GW 322 & 34.57 & 29.63 & 24.69 & 29.63 & 1.02 & -0.36 & MR \\
\hline 2 & HI $8728(d)$ & 49.38 & 43.21 & 39.51 & 44.03 & 1.02 & 0.76 & MS \\
\hline 3 & HI 8498 (d) & 51.85 & 49.38 & 43.21 & 48.15 & 0.90 & 1.79 & MS \\
\hline 4 & HI 8713(d) & 49.21 & 43.21 & 39.51 & 43.98 & 1.00 & 0.61 & MS \\
\hline 5 & HI 1544 & 51.85 & 49.38 & 43.21 & 48.15 & 0.90 & 1.78 & MS \\
\hline 6 & HI 8726(d) & 34.57 & 29.63 & 25.93 & 30.04 & 0.89 & -0.07 & MR \\
\hline 7 & HI 8727(d) & 51.85 & 49.38 & 43.21 & 48.15 & 0.90 & 1.78 & MS \\
\hline 8 & MACS $3828(d)$ & 51.85 & 49.57 & 39.51 & 46.97 & 1.28 & 9.31 & MS \\
\hline 9 & GW 1277(d) & 51.85 & 43.21 & 43.21 & 46.09 & 0.89 & 12.40 & MS \\
\hline 10 & GW 428 & 51.85 & 49.38 & 39.51 & 46.91 & 1.28 & 8.40 & MS \\
\hline 11 & HI 8725(d) & 51.85 & 43.21 & 41.57 & 45.54 & 1.06 & 8.12 & MS \\
\hline 12 & MP 1259 & 29.63 & 25.92 & 18.52 & 24.69 & 1.15 & 1.73 & MR \\
\hline 13 & MPO 1262(d) & 51.85 & 49.38 & 43.21 & 48.15 & 0.90 & 1.79 & MS \\
\hline 14 & PDW 327(d) & 51.85 & 43.21 & 41.57 & 45.54 & 1.06 & 8.09 & MS \\
\hline 15 & MPO 1215 (d) & 51.85 & 49.38 & 39.51 & 46.91 & 1.28 & 8.38 & MS \\
\hline 16 & GW 1276(d) & 51.85 & 49.38 & 41.57 & 47.60 & 1.07 & 4.16 & MS \\
\hline 17 & MPO 1255(d) & 34.57 & 29.63 & 24.69 & 29.63 & 1.02 & -0.36 & MR \\
\hline 18 & UAS 442(d) & 51.85 & 49.38 & 43.21 & 48.15 & 0.90 & 1.79 & MS \\
\hline 19 & HI 8627 (d) & 51.85 & 39.51 & 49.38 & 46.91 & 0.25 & 82.15 & MS \\
\hline 20 & A-9-30-1 & 51.85 & 43.57 & 49.38 & 48.27 & 0.25 & 32.91 & MS \\
\hline 21 & HP 1940 & 34.57 & 29.63 & 25.93 & 30.04 & 0.90 & -0.07 & MR \\
\hline 22 & MPO 1256(d) & 34.57 & 25.93 & 18.52 & 26.34 & 1.66 & -0.02 & MR \\
\hline 23 & GW 1280(d) & 34.57 & 36.57 & 34.57 & 35.24 & 0.00 & 2.29 & MR \\
\hline 24 & HI 8730(d) & 34.57 & 29.63 & 25.93 & 30.04 & 0.90 & -0.07 & MR \\
\hline 25 & HI 1500 & 25.92 & 24.69 & 18.52 & 23.04 & 0.77 & 3.55 & MR \\
\hline 26 & HI 8731(d) & 51.85 & 43.21 & 39.57 & 44.88 & 1.27 & 4.07 & MS \\
\hline 27 & MP 4010 & 69.14 & 66.67 & 59.26 & 65.02 & 1.03 & 3.48 & $\mathrm{~S}$ \\
\hline 28 & HD 2864 & 77.78 & 69.13 & 64.21 & 70.37 & 1.40 & 2.17 & S \\
\hline 29 & MP 3336 & 69.14 & 66.67 & 59.26 & 65.02 & 1.03 & 3.48 & $\mathrm{~S}$ \\
\hline 30 & DBW 90 & 55.85 & 51.85 & 43.21 & 50.30 & 1.31 & 2.98 & MS \\
\hline 31 & GW 433 & 51.85 & 41.57 & 43.21 & 45.54 & 0.89 & 23.75 & MS \\
\hline 32 & UP 2824 & 69.14 & 66.67 & 59.26 & 65.02 & 1.03 & 3.49 & $\mathrm{~S}$ \\
\hline 33 & HD 3095 & 55.85 & 51.85 & 39.51 & 49.07 & 1.70 & 10.66 & MS \\
\hline \multirow[t]{4}{*}{34} & HD 2932 & 53.85 & 51.85 & 43.21 & 49.64 & 1.11 & 6.69 & MS \\
\hline & & & \multicolumn{2}{|c|}{\begin{tabular}{l|l} 
Variety $(V)$ & En
\end{tabular}} & onment & $\mathbf{V} \times \mathbf{E}$ & & \\
\hline & \multicolumn{2}{|c|}{$\operatorname{SEm}( \pm)$} & \multicolumn{2}{|c|}{0.351} & \multicolumn{2}{|c|}{0.283} & & \\
\hline & \multicolumn{2}{|c|}{$\mathrm{CD}(\mathrm{P}=\mathbf{0 . 0 5})$} & 0.977 & & 0.789 & 1.693 & & \\
\hline
\end{tabular}


Table.7 Mean Disease severity (PDI) and parameters of stability (bi and $\mathrm{S}^{2} \mathrm{di}$ ) on wheat varieties of North Western Plain zone at hard dough stage grown in three environments (2015-2018)

\begin{tabular}{|c|c|c|c|c|c|c|c|c|}
\hline \multirow[t]{2}{*}{$\begin{array}{l}\text { SL } \\
\text { No. }\end{array}$} & \multirow[t]{2}{*}{ Varieties } & \multicolumn{3}{|c|}{$\begin{array}{l}\text { Percent disease incidence } \\
\text { (PDI) }\end{array}$} & \multirow[t]{2}{*}{ Mean } & \multirow{2}{*}{$\begin{array}{c}\text { Regression } \\
\text { coefficient } \\
\text { (bi) }\end{array}$} & \multirow{2}{*}{$\begin{array}{c}\text { Mean } \\
\text { deviation } \\
\left(\mathbf{S}^{2} \text { di }\right)\end{array}$} & \multirow{2}{*}{$\begin{array}{c}\text { Disease } \\
\text { reactio } \\
\mathbf{n}\end{array}$} \\
\hline & & 2015-16 & 2016-17 & 2017-18 & & & & \\
\hline 1 & PBW 343 & 41.85 & 43.21 & 39.51 & 41.52 & 0.58 & 0.48 & MS \\
\hline 2 & HD 3081 & 53.85 & 51.85 & 45.85 & 50.52 & 1.39 & 0.79 & MS \\
\hline 3 & HD 3077 & 41.85 & 43.21 & 39.51 & 41.52 & 0.58 & 0.48 & MS \\
\hline 4 & HD 3080 & 24.69 & 29.63 & 25.93 & 26.75 & 0.21 & 11.81 & MR \\
\hline 5 & PBW 665 & 22.22 & 24.69 & 18.52 & 21.81 & 0.95 & 2.98 & MR \\
\hline 6 & HD 3086 & 41.85 & 43.21 & 39.51 & 41.52 & 0.58 & 0.48 & MS \\
\hline 7 & PBW 662 & 54.85 & 51.85 & 43.21 & 49.97 & 2.01 & 2.60 & MS \\
\hline 8 & WH 1105 & 45.21 & 43.21 & 39.57 & 42.66 & 0.92 & 0.98 & MS \\
\hline 9 & TL 2978 & 54.85 & 51.85 & 43.21 & 49.97 & 2.01 & 2.61 & MS \\
\hline 10 & DBW 17 & 43.21 & 41.57 & 39.51 & 41.43 & 0.58 & 0.51 & MS \\
\hline 11 & DBW 88 & 34.57 & 29.63 & 25.93 & 30.04 & 1.24 & 10.23 & MR \\
\hline 12 & DPW 621-50 & 69.14 & 66.67 & 63.21 & 66.34 & 0.94 & 1.91 & $\mathrm{~S}$ \\
\hline 13 & WH 1120 & 54.85 & 51.85 & 45.85 & 50.85 & 1.49 & 2.91 & MS \\
\hline 14 & PDW 291 & 51.85 & 49.38 & 43.57 & 48.27 & 1.40 & 1.68 & MS \\
\hline 15 & HD 4725 & 43.21 & 49.38 & 43.21 & 45.27 & 0.56 & 19.23 & MS \\
\hline 16 & WHD 950 & 71.22 & 69.14 & 66.67 & 69.01 & 0.70 & 1.22 & $\mathrm{~S}$ \\
\hline 17 & HI 8727 & 69.14 & 77.78 & 66.67 & 71.19 & 1.27 & 39.30 & $\mathrm{~S}$ \\
\hline 18 & PDW 314 & 66.67 & 71.22 & 59.26 & 65.72 & 1.87 & 11.77 & $\mathrm{~S}$ \\
\hline 19 & WHD 948 & 69.14 & 69.14 & 66.67 & 68.31 & 0.48 & -0.63 & $\mathrm{~S}$ \\
\hline 20 & HI 8724 & 66.67 & 71.22 & 64.85 & 67.58 & 0.77 & 10.57 & $\mathrm{~S}$ \\
\hline 21 & MACS 3828 & 69.14 & 66.67 & 64.85 & 66.88 & 0.61 & 2.09 & S \\
\hline 22 & HI 8728 & 71.13 & 69.13 & 66.67 & 68.98 & 0.69 & 1.07 & $S$ \\
\hline 23 & AKDW 4749 & 69.14 & 71.13 & 64.85 & 68.37 & 1.02 & 1.85 & $\mathrm{~S}$ \\
\hline 24 & DBW 17 & 69.14 & 69.14 & 66.67 & 68.31 & 0.48 & -0.63 & $\mathrm{~S}$ \\
\hline 25 & DBW 90 & 66.67 & 69.14 & 64.85 & 66.89 & 0.58 & 2.77 & S \\
\hline 26 & HD 3059 & 77.78 & 69.14 & 66.67 & 71.19 & 1.39 & 34.06 & S \\
\hline 27 & HD 3091 & 66.67 & 64.85 & 59.26 & 63.59 & 1.29 & 0.52 & $\mathrm{~S}$ \\
\hline 28 & WH 1021 & 69.14 & 66.67 & 63.21 & 66.34 & 0.94 & 1.92 & $\mathrm{~S}$ \\
\hline \multirow[t]{2}{*}{29} & HD 3065 & 51.85 & 49.38 & 43.21 & 48.15 & 1.47 & 1.65 & MS \\
\hline & & $\begin{array}{l}\text { Variety } \\
\text { (V) }\end{array}$ & \multicolumn{2}{|c|}{$\begin{array}{c}\text { Environment } \\
\text { (E) }\end{array}$} & $\mathbf{V} \times \mathbf{E}$ & & & \\
\hline & $\operatorname{SEm}( \pm)$ & 0.460 & \multicolumn{2}{|c|}{0.364} & 0.796 & & & \\
\hline \multicolumn{2}{|c|}{$\mathrm{CD}(\mathrm{P}=0.05)$} & 1.283 & \multicolumn{2}{|c|}{1.015} & 2.223 & & & \\
\hline
\end{tabular}




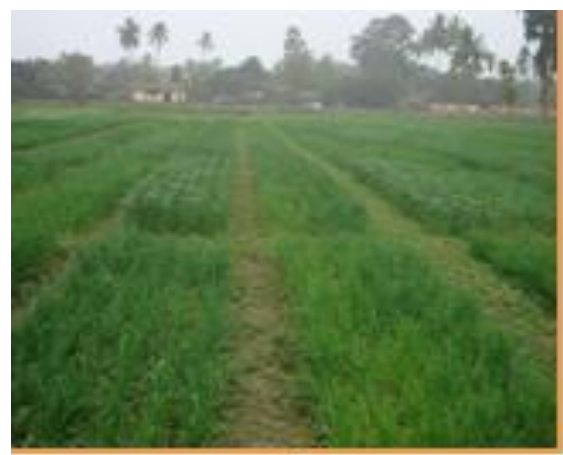

A

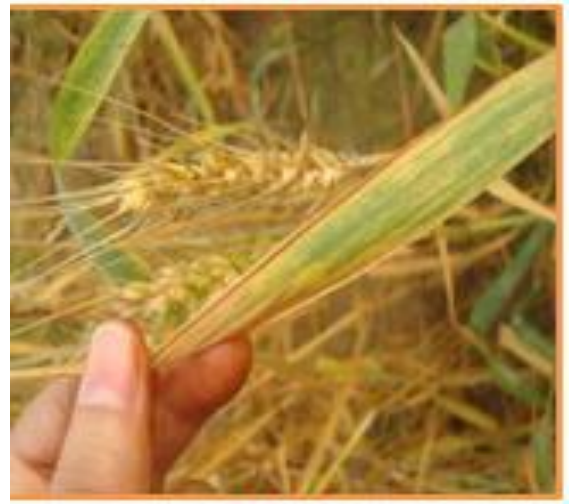

D

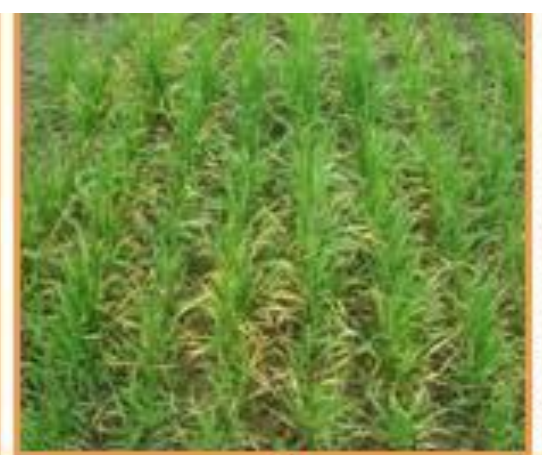

B

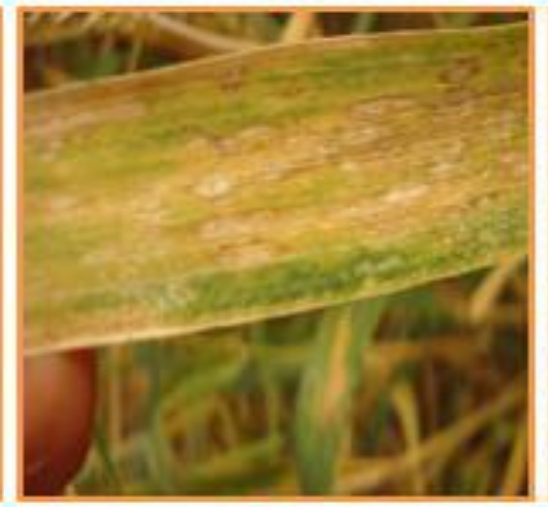

E

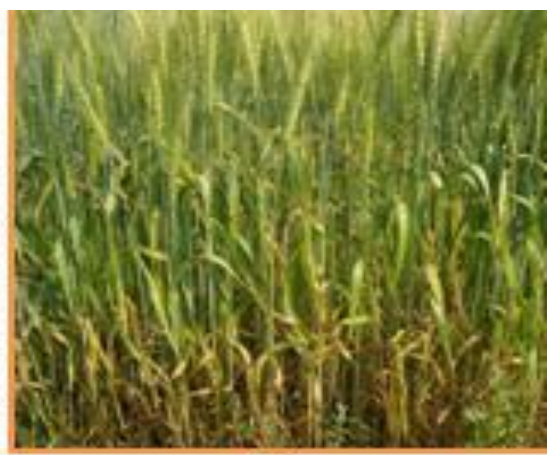

C

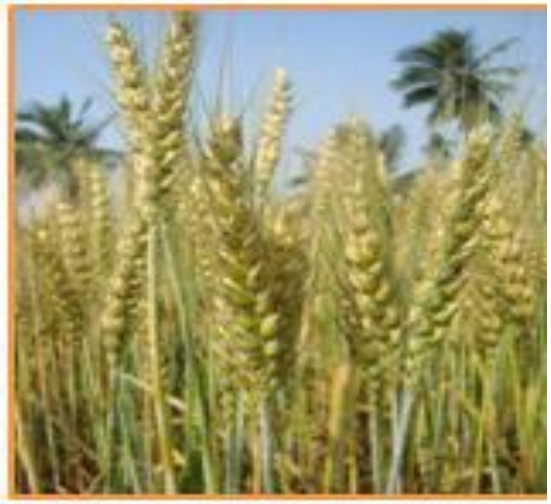

$\mathbf{F}$

Plate.1 (A) General view of experimental trial, (B) spot blotch infection at seedlings stage, (C) Infection at dough stage, (D) Coalescing spots leading to spot blotch, (E) Black powdery conidia covering the lesions $(\mathrm{F})$ Affected grains at the time of harvest

Plate.2 Artificial inoculation under field condition
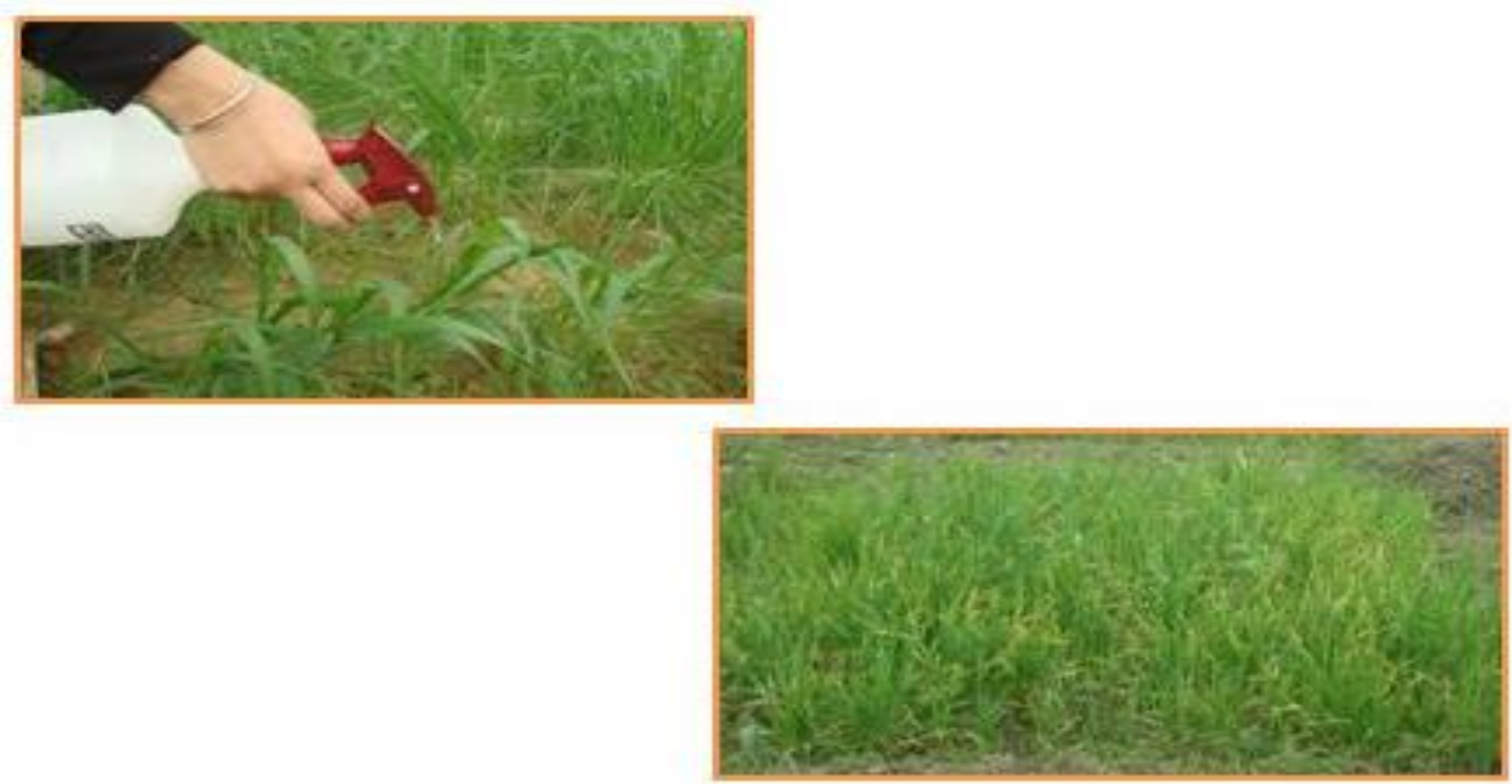

Plate.2 Artificial inoculation under field condition 
Table.8 Mean Disease severity (PDI) and parameters of stability (bi and $\mathrm{S}^{2}$ di) on wheat varieties of Penninsular zone at hard dough stage grown in three environments (2015-2018)

\begin{tabular}{|c|c|c|c|c|c|c|c|c|}
\hline \multirow{2}{*}{$\begin{array}{l}\text { SL } \\
\text { No. }\end{array}$} & \multirow[t]{2}{*}{ Varieties } & \multicolumn{3}{|c|}{ Percent disease incidence (PDI) } & \multirow[t]{2}{*}{ Mean } & \multirow{2}{*}{$\begin{array}{l}\text { Regression } \\
\text { coefficient } \\
\text { (bi) }\end{array}$} & \multirow{2}{*}{$\begin{array}{c}\text { Mean } \\
\text { deviation } \\
\left(\mathbf{S}^{2} \text { di }\right)\end{array}$} & \multirow{2}{*}{$\begin{array}{c}\text { Disease } \\
\text { reactio } \\
\mathbf{n}\end{array}$} \\
\hline & & 2015-16 & 2016-17 & 2017-18 & & & & \\
\hline 1 & HI 8728 (d) & 34.57 & 29.63 & 25.93 & 30.04 & 0.83 & 0.61 & MR \\
\hline 2 & HI 1584 & 39.51 & 43.21 & 39.51 & 40.74 & 0.03 & 8.74 & MS \\
\hline 3 & HI 8725 (d) & 29.63 & 34.57 & 25.93 & 30.04 & 0.42 & 28.04 & MR \\
\hline 4 & UAS 336 & 49.38 & 43.21 & 39.51 & 44.03 & 0.94 & 2.04 & MS \\
\hline 5 & UAS 428 & 55.38 & 49.38 & 39.51 & 48.09 & 1.55 & 0.17 & MS \\
\hline 6 & UAS 334 & 51.85 & 43.21 & 39.51 & 44.86 & 1.17 & 6.84 & MS \\
\hline 7 & MACS 6222 & 29.63 & 24.69 & 18.52 & 24.28 & 1.08 & -0.33 & MR \\
\hline 8 & NIDW 295(d) & 34.57 & 29.63 & 25.93 & 30.04 & 0.83 & 0.61 & MR \\
\hline 9 & PDW 329 (d) & 49.38 & 43.21 & 39.51 & 44.03 & 0.94 & 2.04 & MS \\
\hline 10 & UAS 439 (d) & 51.85 & 43.21 & 39.51 & 44.86 & 1.17 & 6.85 & MS \\
\hline 11 & AKAW 4731 & 25.92 & 29.63 & 24.69 & 26.75 & 0.16 & 11.59 & MR \\
\hline 12 & NIAW 1773 & 55.85 & 51.85 & 43.21 & 50.30 & 1.24 & 1.11 & MS \\
\hline 13 & WHD 948 (d) & 51.85 & 43.21 & 39.51 & 44.86 & 1.17 & 6.86 & MS \\
\hline 14 & HI $8724(d)$ & 55.85 & 43.21 & 39.51 & 46.19 & 1.54 & 20.15 & MS \\
\hline 15 & MACS 3817(d) & 51.85 & 49.38 & 43.21 & 48.15 & 0.85 & 0.75 & MS \\
\hline 16 & RAJ 4083 & 55.85 & 51.85 & 39.51 & 49.07 & 1.61 & 5.97 & MS \\
\hline 17 & HD 2932 & 77.78 & 69.14 & 66.67 & 71.19 & 1.04 & 9.38 & $\mathrm{~S}$ \\
\hline 18 & HD 3090 & 55.85 & 51.85 & 43.21 & 50.30 & 1.24 & 1.10 & MS \\
\hline \multirow[t]{2}{*}{19} & HD 3096 & 51.85 & 49.38 & 39.51 & 46.91 & 1.22 & 5.17 & MS \\
\hline & & Variety (V) & \multicolumn{2}{|c|}{ Environment (E) } & $\mathbf{V} \times \mathbf{E}$ & & & \\
\hline & $\operatorname{SEm}( \pm)$ & 0.334 & \multicolumn{2}{|c|}{0.194} & 0.579 & & & \\
\hline & $\mathrm{CD}(\mathrm{P}=\mathbf{0 . 0 5})$ & 0.937 & \multicolumn{2}{|c|}{0.543} & 1.623 & & & \\
\hline
\end{tabular}

Based on the disease tolerance reaction out of the 117 genotypes tested genotypes K 8027, C 306 and Raj 4240 from NEPZ and HI 8730, HI 8726(d), MP 1259, GW 1280(d) and HI 1500 from CZ, PBW 665 from NWPZ and HI 8728, HI 8725, MACS 6222, NIDW 295 and AKAW 4731 from PZ could be used to evolve improved genotypes and crop production which are suitable for different agro climatic conditions.

It is expected that this genotype will provide the necessary genes for developing the much sought after stable resistant genotypes.

\section{References}

Annual Report. (2018-19) ICAR - Indian Institute of Wheat and Barley Research, Karnal-132001, Haryana, India.

Chaurasia, S., Joshi, A.K., Dhari, R., Chand, R. 1999. Resistance to foliar blight of wheat: A search. Genet. Res. Crop Evol. 46: 469-475.

Chowdhury, A.K., Singh, G., Tyagi, B.S., Ojha, A., Dhar, T., Bhattacharya, P.M.2013. Spot blotch disease of wheat - a new thrust area for sustaining productivity. J. Wheat Res. 5(2):1-11. 
Derera, N.F., Bhatt, G.M. and McMaster, G.J.1977.On the problem of pre-harvest sprouting of wheat. Euphytica 26, 299308

https://doi.org/10.1007/BF00026991

Devi, H.M., Mahapatra, S. and Das, S.2018.Assessment of yield loss of wheat caused by spot blotch using regression model. Indian Phytopathology. https://doi.org/10.1007/s42360-0180036-9.

Devi, H.M., Mahapatra, S., Dutta, S. and Das, S.2017. Influence of phenological growth stages and meteorological parameters on leaf blight infestation of wheat in Gangetic plains of West Bengal. Journal of Wheat Research. 9(2): 101-107.

Eberhart, S.A. and Russell W.A.1966. Stability parameters for comparing varieties. Crop Science. 6:36-40.

ICAR-IIWBR (2018). Progress Report of AICRP on Wheat and Barley 201718, Social Sciences. Eds: Satyavir Singh, Anuj Kumar, Sendhil R and GP Singh. ICAR-Indian Institute of Wheat and Barley Research, Karnal, India. p. 50 .

Joshi A.K., Ortiz-Ferrara G, Crossa J. 2007. Associations of environments in South Asia based on spot blotch disease of wheat caused by Bipolaris sorokiniana. Crop Science 47, 1071-81.

Joshi, A.K., Ferrara, G.O., Crossa, J., Singh, G., Sharma, R.C., Chand, R., Parsad, R.2007. Combining superior agronomic performance and terminal heat tolerance with resistance to spot blotch (Bipolaris sorokiniana) of wheat in the warm humid Gangetic Plains of South Asia. Field Crops Res. 103:53-61.

Joshi, A.K., Kumar, S., Chand, R., OrtizFerrara, G.2004. Inheritance of resistance to spot blotch caused by Bipolaris sorokiniana in spring wheat.
Plant Breed. 123: 213-219.

Khan, H., Chowdhury, S. 2011. Identification of resistance source in wheat germplasm against spot blotch disease caused by Bipolaris sorokiniana. Archives Phyto. Plant Prot. 44(9):840844.

Kumar, S., Archak, S., Tyagi, R.K.2016. Evaluation of 19,460 wheat accessions conserved in the Indian national genebank to identify new sources of resistance to rust and spot blotch diseases. PLoS One 11:e0167702.

Kumar, S., Prasad, L.C., Kumar, U., Tyagi, K., Arun, B., Joshi, A.K.2007. Inheritance and allelic relationship of resistance genes to spot blotch of wheat caused by Bipolaris sorokiniana. In: Buck, H.T., Nisi, J.E., Salomón, N. (eds) Developments in plant breeding vol 12: wheat production in stressed environments. Springer, The Netherlands, pp. 113-118.

Kumar, S., Singhora, G., Bharadwaj, S.C., Bala, R., Saharan, M.S., Gupta, V., Khan, A., Mahapatra, S., Sivasamy, M., Rana, V., Misra, C.N., Prakash, O., Verma, A., Sharma, P., Sharma, I., Chatrath, R. and Singh, G.P.2019. Multienvironmental evaluation of wheat (Triticum aestivum L.) germplasm identifies donors with multiple fungal disease resistance. Genetic Resources and Crop Evolution. DOI: 10.1007/s10722-019-00751-3.

Kumar, S., Singroha, G., Bhardwaj, S.C., Saharan, M.S., Gangwar, O.P., Mishra, C.N., Khan, A., Mahapatra, S., Sivasamy, M., Chatrath, R. and Singh, G.P. 2020. Characterization of exotic germplasm lines for resistance to wheat rusts and spot blotch. Indian Phytopath. 73, 237-243 (2020) https://doi.org/10.1007/s42360-02000232-z

Mudi,N., Mahapatra, S. and Das, 
S.2010.Screening of Barley cultivars against Helminthosporium sativum and the stability of disease reaction and yield. Indian Phytopathology. 63(1):9193

Pandey, S. and Tewari, A.N. 1999.Field evaluation of wheat varieties against leaf blight and its control. Plant Disease Research. 14(1): 52-54.

Prabhu, A. S. and Singh, A.1974. Appraisal of yield losses in wheat due to foliage diseases caused by Alternaria triticina and Helminthosporium sativum. Indian Phytopathology, 27: 632-634.

Saari, E. E. and Prescott, S. M.1975. A scale for apprising the foliar intensity of wheat diseases. Plant Dis. Reptr. 59: 377-380.

Sharma, R.C., Duveiller, E., Kandel, Y.R. and Shreshta, S.M.2005. Epidemiology of foliar blight (spot blotch and tan spot) of wheat in the plains bordering the Himalayas. Phytopathol. 95(3): 248256.
Singh, D.P., Sharma, I., Singh, I., Jindal, M., Mann, K.S., Chowdhury, A.K., Mahapatra, S., Singh, K.P., Kumar, J., Deepshikha, Srivastava, K., Vaish, K. K., Chand, R., Dodan, D.S., Singh, S. P., Verma, J., Das, S.Y., Karswara, S.S., Pradhan, A.C., Mukhopadhyay, S.K., Dutta, S., Kalappanavar, I.K., Solanki, I.S., Kumar, A., Azad, G.C. and Lal, H.C. 2015. Evaluation of sources of resistance of leaf blight (Bipolaris sorokiniana and Alternaria triticina) in wheat (Triticum aestivum) and Triticale. Indian Phytopathology. 68(2): 221-222.

Singh, P.K., Zhang, Y., He, X.2015. Development and characterization of the 4th CSISA-spot blotch nursery of bread wheat. European Journal of Plant Pathology, 143, 595-605.

Zadoks, J.C., Chang, T.T. and Konzak, C.F.1974. A decimal code the growth stages of cereals. Weed Res. 14:415421.

\section{How to cite this article:}

Sunita Mahapatra, Hizam Meronbala Devi, Satish Kumar, Dhiman Mukherjee and Srikanta Das. 2020. Performance and Stability of Different Zone Specific Genotypes Evaluated against Spot Blotch of Wheat. Int.J.Curr.Microbiol.App.Sci. 9(06): 2968-2981. doi: https://doi.org/10.20546/ijcmas.2020.906.357 